\title{
Aleksander Klemp \\ (21 II 1948 - 10 XI 2019)
}

Aleksander Klemp, urodzony w Gdańsku 21 II 1948 r., pochodził z rodziny osiadłej od schyłku XVIII w. w Borach Tucholskich. Dalekie pokrewieństwo łączyło go z toruńskim działaczem społecznym i politycznym dr. Ottonem Steinbornem, którego matką była Elżbieta z Klempów. Ojciec Aleksandra Antoni urodził się w Toruniu, ale po drugiej wojnie światowej przeniósł się do Gdańska. Matka Aniela z domu Żurek pochodziła z okolic Kępna w Wielkopolsce. Aleksander szkołę podstawową ukończył w Gdyni, po czym od 1962 r. uczył się tamże w I Liceum Ogólnokształcącym. W latach 1967-1972 odbył studia historyczne na Uniwersytecie Gdańskim, uczęszczając na seminarium magisterskie prof. Wacława Odyńca. Od 1972 r. był asystentem w Katedrze Historii Nowożytnej. Potem przez krótki czas, pracował w Bibliotece Głównej Uniwersytetu Gdańskiego. Od maja do grudnia 1981 r. był zatrudniony w Ośrodku Prac Społeczno-Zawodowych w gdańskiej centrali „Solidarności", przygotowując wraz z zespołem edycję zbioru źródeł dotyczących wydarzeń grudniowych $1970 \mathrm{r}$. na Wybrzeżu1. Dnia 1 II 1982 r. przeszedł do pracy w Bibliotece Gdańskiej Polskiej Akademii Nauk, obejmując z czasem funkcję kierownika Działu Wydawnictw Ciągłych, a następnie Działu Gromadzenia i Uzupełniania Zbiorów. W 1986 r. ukończył Podyplomowe Studium Bibliotekarskie.

Od czasów studenckich interesował się historią szeroko pojętego Pomorza w czasach nowożytnych. Jako asystent zaczął studia nad protestancką szlachtą na tym obszarze w XVII-XVIII w. Pierwszą jego drukowaną publikacją była recenzja z obszernej edycji źródłowej Księga wpisów uczniów Gimnazjum Gdańskiego 1580-18142. Większość swoich prac naukowych opublikował już jako pracownik Biblioteki Gdańskiej PAN. Najważniejszą z nich była rozprawa doktorska obroniona w 1992 r. na Uniwersytecie Gdańskim. W postaci książkowej ukazała się ona w Gdańsku w 1994 r. pt. Protestanci w dobrach prywatnych $w$ Prusach Królewskich od drugiej połowy XVII do drugiej połowy XVIII wieku $u^{3}$. Spotkała się też z pochlebnymi recenzjami Wojciecha Kriegseisena,

${ }^{1}$ Grudzień 1970, dir. Piotr Jegliński, Paris 1986.

${ }^{2}$ Aleksander KLEMP, [rec.] Księga wpisów uczniów Gimnazjum Gdańskiego 1580-1814, opr. Zbigniew NowaK, Przemysław Szafran, Rocznik Gdański, t. 37: 1977, s. 160-163.

${ }^{3}$ Idem, Protestanci $w$ dobrach prywatnych $w$ Prusach Królewskich od drugiej połowy XVII do drugiej połowy XVIII wieku, Gdańsk-Wrocław 1994. 
Zygmunta Szultki i Jerzego Dygdały. Ostatni z recenzentów podkreślił, że rozprawa ma znacznie szerszy zasięg chronologiczny, faktycznie obejmuje bowiem okres od początków reformacji protestanckiej w XVI w. do 1772 r., potwierdza też hipotezę o znaczącym wpływie starostów na szerzenie się reformacji na wiejskich obszarach Pomorza Nadwiślańskiego. Recenzent zwrócił też uwagę, że książka ta jest oparta na bardzo bogatym materiale źródłowym (archiwalnym) i przynosi wiele nowych informacji biograficznych. Już wcześniej ukazała się niewielka książka autorstwa Aleksandra Klempa pt. Katedra oliwska. Fundacja i nekropolia książąt gdańsko-pomorskich ${ }^{4}$.

Do ważnych osiągnięć dra Klempa trzeba zaliczyć udział w autorstwie w dwóch monografiach miast pomorskich. W dwutomowym wyborze tekstów źródłowych do dziejów Starogardu Gdańskiego opublikował on materiały dotyczące historii tego miasta w czasach Rzeczypospolitej szlacheckiej XVI-XVIII w. ${ }^{5}$, a także opracował dzieje Wejherowa w latach 1643-1772 ${ }^{6}$. Jest on też autorem kilkunastu artykułów poświęconych stosunkom wyznaniowym na Pomorzu (zwłaszcza w ziemi lęborskiej), ewangelikom gdańskim pochodzenia polskiego oraz tzw. sarmatyzacji niektórych mieszczańskich rodzin osiadłych w Gdańsku. Opracował też kilka biogramów w Słowniku biograficznym Pomorza Nadwiślańskiego. Recenzował monografie autorstwa m.in. Zygmunta Szultki, Krzysztofa Mikulskiego i Mariana Pawlaka. Wnikliwie, wprowadzając sporo uzupełnień, omówił edycję źródłową Jerzego Dygdały ${ }^{7}$.

Odrębne miejsce zajmowały w jego twórczości publikacje poświęcone zbiorom Biblioteki Gdańskiej PAN. Pisał m.in. o japonikach w gdańskich księgozbiorach XVI-XIX w. ${ }^{8}$ czy o gmachu tejże biblioteki ${ }^{9}$. Pośrednio z tą problematyką związana jest ostatnia większa praca dra Aleksandra Klempa. Uczestniczył on w edycji okolicznościowych mów wygłoszonych w Gdańsku w 1790 r. przy okazji przekazania miastu w darze od króla Stanisława Augusta popiersia gdańskiego astronoma Jana Heweliusza. To bibliofilskie wydanie

\footnotetext{
${ }^{4}$ Idem, Katedra oliwska. Fundacja i nekropolia książąt gdańsko-pomorskich, Gdańsk 1987.

${ }^{5}$ Idem, Starogard w okresie Polski szlacheckiej (od XVI - do XVIII wieku), [in:] Księga Jubileuszowa Królewskiego Miasta Starogard, t. 1, red. Józef BorzYszKowsкi, Starogard-Gdańsk 1998, s. 65-138.

${ }^{6}$ Idem, Wejherowo w latach 1643-1772, [in:] Historia Wejherowa, red. Józef BonzyszkowSKI, Wejherowo 1998, s. 57-97.

${ }^{7}$ Idem, Uwagi o edycji lustracji województwa pomorskiego z 1765 roku, Zapiski Historyczne, t. $73: 2008$, z. 4, s. 145-157.

${ }^{8}$ Idem, Obraz Japonii na łamach czasopism i w literaturze. Japonika w gdańskich księgozbiorach (XVI - 1 poł. XIX wieku), [in:] Japonia w oczach Polaków. Państwo, społeczeństwo, kultura, red. Józef WıODARSKI, Gdańsk 2008, s. 75-84.

${ }^{9}$ Idem, Nowa siedziba Biblioteki Gdańskiej z 1905 roku, Libri Gedanenses, t. 22: 2004, s. $151-159$.
} 
dr Klemp zaopatrzył obszernym posłowiem ${ }^{10}$. Warto przypomnieć, że brał też czynny udział w licznych konferencjach naukowych poświęconych przeszłości Pomorza, wygłaszając tam referaty i uczestnicząc w dyskusjach.

Doktor Aleksander Klemp był wyjątkowym znawcą zasobów Biblioteki Gdańskiej PAN, zawsze można było liczyć na jego pomoc. Dzięki m.in. jego wskazówkom znalazłem odbitki fotografii wspaniałego barokowego pałacu Przebendowskich, wykonane tuż przed rozbiórką tej budowli w końcu XIX w. ${ }^{11}$

Od 1979 r. czynnie działał w Zrzeszeniu Kaszubsko-Pomorskim, pełniąc tam m.in. funkcje przewodniczącego Głównej Komisji Rewizyjnej i sekretarza generalnego. Aktywnie angażował się w różne przedsięwzięcia upamiętniające przeszłość Pomorza, zwłaszcza miasta, w którym mieszkał - Gdyni. Był m.in. wiceprzewodniczącym gdyńskiego Koła Unii Demokratycznej w Gdyni.

Mimo ogromnej wiedzy i wielu zainteresowań odznaczał się wyjątkową skromnością, dlatego też nie zawsze potrafił zabiegać o publikacje wyników swoich badań. Od dawna prowadził kwerendy źródłowe dotyczące kultury szlachty Prus Królewskich w XVII stuleciu, a także początków genealogii rodziny Przebendowskich (miał do tego tematu zebranych sporo materiałów). Niestety postępująca choroba serca nie pozwoliła mu sfinalizować tych pomysłów. Od czerwca 2007 r. był na rencie, w 2008 r. przeszedł na emeryturę. Zmarł 10 XI 2019 r. na Oddziale Kardiologii Szpitala Miejskiego w Gdyni. Od 1973 r. był żonaty z nauczycielką historii Jadwigą Nawrocką.

\section{Jerzy Dygdała* \\ iD https://orcid.org/0000-0002-9804-6845}

${ }^{10}$ Idem, Dar króla polskiego dla Gdańska z 1790 roku, [in:] Od króla Stanisława Augusta dar dla Gdańska, tł. Stefania SychtA, opr. Aleksander KLEmP, Gdańsk 2008, s. 63-88.

${ }^{11}$ Zob. Jerzy DygdaŁA, Pałac podskarbiego wielkiego koronnego Jana Jerzego Przebendowskiego w Leźnie koło Gdańska w pierwszej połowie XVIII wieku, Zapiski Historyczne, t. 81: 2016, z. 1, s. 37-62, DOI: http://dx.doi.org/10.15762/ZH.2016.02.

* Instytut Historii im. Tadeusza Manteuffla, Polska Akademia Nauk, @ jdygdala@ihpan.edu.pl 